\title{
Analisis Perbandingan Kinerja Metode Superpixel dan Gradien berbasis Edge Detector pada Pendeteksian Objek Bergerak
}

\author{
MUHAMMAD KHAERUL NAIM MURSALIM, IHSAN VERDIAN \\ Program Studi Teknik Telekomunikasi Universitas Universal \\ Email: muh.khaerul.naim@gmail.com
}

Received 12 Desember 2019 | Revised 7 Februari 2020 | Accepted 4 Maret 2020

\begin{abstract}
ABSTRAK
Salah satu bagian dalam algoritma pemrosesan citra adalah proses segmentasi yang menjadi tahap pra-pemrosesan untuk ekstraksi fitur objek. Superpixel menjadi salah satu solusi pada proses segmentasi dengan mendefenisikan kumpulan piksel yang mempunyai kesamaan karekterisitik sehingga membawa banyak informasi mengenai fitur objek. Adapun tantangan yang dihadapi dalam mendeteksi objek bergerak adalah ketidakmampuan untuk memisahkan objek bergerak dari background objek. Sehingga, pada citra yang dideteksi akan dikelilingi oleh wilayah yang terdapat derau. Pada penelitian ini, diusulkan metode superpixel berbasis deteksi tepi untuk mendeteksi objek bergerak. Selanjutnya, kinerja metode superpixel diuji dengan membandingkan dengan metode deteksi tepi yang berbasis gradient. Hasilnya menunjukkan bahwa metode yang diusulkan mampu meminimalisir derau lebih baik dan hasil perhitungan MSE, RMSE, dan PSNR hanya berbeda $0.06 \%$ dan $0.1 \%$ dari metode Sobel dan Prewitt.
\end{abstract}

Kata kunci: Deteksi tepi, Objek bergerak, Proses Segmentasi, Superpixel

\begin{abstract}
One part of the image processing is the segmentation which becomes the preprocessing stage for feature extraction. Superpixel becomes solutions in the segmentation process by defining a collection of pixels that have the same characteristics ang bringing the information about the object's features. The challenge faced in detecting moving objects is the inability to separate moving objects from the object's background. Thus, the detected image will be surrounded by an area with noise. In this study, a superpixel-based edge detection method is proposed to detect moving objects. Furthermore, the performance of the superpixel method is tested by comparing it to the gradient-based edge detection method. The results show that the proposed method is able to minimize noise better and the results of MSE, RMSE, and PSNR calculations differ only $0.06 \%$ and $0.1 \%$ from the Sobel and Prewitt methods.
\end{abstract}

Keywords: Edge detection, Moving objects, Segmentation, Superpixels 
Analisis Perbandingan Kinerja Metode Superpixe/ dan Gradien berbasis Edge Detector pada

Pendeteksian Objek Bergerak

\section{PENDAHULUAN}

Salah satu bagian penting dalam metode pemrosesan citra adalah segmentasi gambar yang menjadi tahap pre-processing untuk ekstraksi fitur objek dalam citra yang diamati (Chandwadkar, dkk, 2013). Segmentasi citra melibatkan proses pemisahan citra digital menjadi beberapa kelompok piksel. Salah satu cara untuk mensegmentasi kelompok-kelompok piksel adalah metode superpixel. Superpixe/ dapat didefinisikan sebagai sekelompok piksel yang memiliki karakteristik umum (seperti intensitas piksel, tekstur, warna, tingkat kecerahan, dII). Superpixels menjadi berguna dalam algoritma pemrosesan citra seperti pelabelan semantik, deteksi objek dan pelacakan. Hal ini disebabkan karena superpixe/membawa lebih banyak informasi daripada piksel dan mampu mengurangi kompleksitas pada proses komputasi yang dilakukan (Zhang, dkk, 2019).

Penelitian mengenai metode superpixe/ telah banyak dilakukan selama beberapa tahun terakhir. Metode superpixel yang efektif harus memenuhi beberapa karakteristik seperti compactness, batas tiap superpixe/yang jelas, kompleksitas komputasi, dan jumlah superpixel yang dapat dikendalikan (Wu, dkk, 2018). Beberapa penelitian mengenai metode superpixel memiliki kelebihan dan kekurangannya sendiri. Simple linear iterative clustering (SLIC) adalah metode berbasis pengelompokan piksel yang paling umum digunakan. Metode ini memanfaatkan $K$-means lokal untuk mengelompokkan piksel berdasarkan warna dan jarak spasialnya (Radhakrishna, dkk, 2012). Metode berbasis pengelompokan piksel lainnya yang terkenal yaitu Linear spectral clustering (LSC) (Zhengqin \& Jiansheng, 2015). Berbeda dengan ruang lima-dimensional yang digunakan dalam metode SLIC, pada metode LSC memenfaatkan ruang Sepuluh-dimensional untuk mendapatkan tingkat penentuan batas anatara superpixel yang lebih baik dari SLIC. Pada penelitian selanjutnya, peneliti meningkatkan kemampuan metode SLIC dengan menghilangkan proses iterasi, sehingga metode ini memiliki efisiensi komputasi dan memori yang lebih tinggi. Metode ini disebut Simple noniterative clustering (SNIC) (Radhakrishna \& Sabine , 2017).

Pada Penelitian ini, mengacu pada konsep superpixel, yang merupakan serangkaian wilayah terdiri dari kumpulan piksel dengan posisi yang berdekatan dan fitur warna, kecerahan dan tekstur yang identik (Xiaofeng \& Jitendra, 2003). Sehingga, wilayah superpixe/ ini dapat menyimpan informasi yang efektif seperti informasi batas objek dalam citra. Hal ini dimanfaatkan untuk mendeteksi tepi objek citra dengan mendeteksi tepi objek pada setiap wilayah superpixel. Deteksi tepi telah banyak digunakan sebagai hasil dari fitur yang diekstraksi (misalnya, garis, kurva dan sudut) dalam segmentasi gambar untuk aplikasi seperti deteksi objek, pengenalan objek, pengambilan video, dan peningkatan kualitas citra. Tujuan deteksi tepi adalah untuk menentukan tiap piksel dalam gambar yang berkorelasi dengan tepi objek yang diamati dalam citra. Tepi pada citra berhubungan dengan kontur yang tingkat kecerahan pixelnya berubah secara drastis. Sebagai bagian dari pemrosesan citra, tepi objek sering didefinisikan sebagai salah satu kelas singularitas yang dapat digunakan untuk mendeteksi objek secara keseluruhan.

Tujuan dari penelitian ini adalah untuk menggunakan metode superpixe/ untuk mendeteksi objek bergerak dengan memanfaatkan fitur tepi objek bergerak tersebut. Pendeteksian objek, khususnya pada objek bergerak memiliki beberapa tantangan yang dihadapi seperti pergerakan objek, jenis objek, jenis lingkungan, pencahayaan, dan jenis kamera (Mursalim, 2018). Salah satu tantangan yang menjadi perhatian pada penelitian ini adalah pergerakan objek. Hal ini disebabkan karena pergerakan objek berisi banyak informasi tentang piksel untuk mendeteksi objek bergerak yang memiliki peran penting sebagai deskriptor objek citra. Namun, pergerakan objek ini juga menimbulkan masalah lain yaitu ketidakmampuan untuk 
memisahkan objek bergerak dari background yang ikut bergerak. Jadi, pada citra yang terdapat objek bergerak akan dikelilingi oleh wilayah yang berisi derau. Salah satu keuntungan menggunakan metode superpixel yang berbasis detektor tepi adalah ketahanan terhadap lingkungan yang terdapat derau. Selanjutnya, pada penelitian ini, kinerja dari metode superpixe/ ini akan dibandingkan dengan dengan berbagai metode deteksi tepi yang berbasis gradien edge detector seperti Sobel, Prewitt, Canny, Roberts, dan LOG difference (Heath, dkk, 1998). Makalah ini disusun sebagai berikut. Bagian II adalah untuk Metodologi penelitian. Bagian III difokuskan pada hasil simulasi dan juga fokus pada perbandingan beberapa Algoritma Deteksi Tepi. Bagian IV menyajikan kesimpulan dari penelitian ini.

\section{METODOLOGI PENELITIAN}

\subsection{Blok diagram Simulasi}

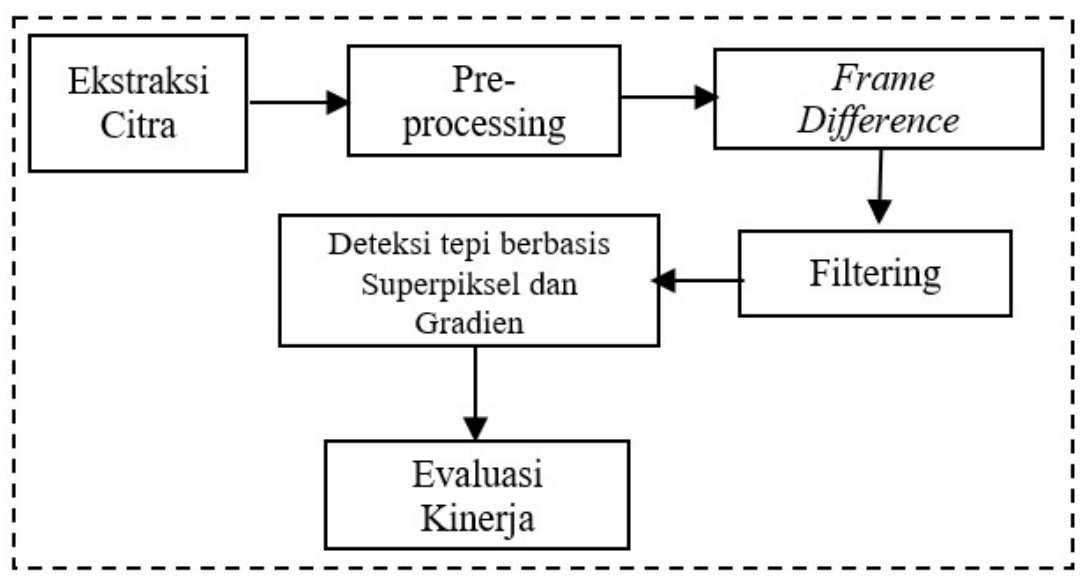

Gambar 1. Blok Diagram Simulasi

Berdasarkan blok diagram simulasi yang ditunjukkan pada Gambar 1. Simulasi dimulai dengan mengekstraksi citra dari video yang merekam pergerakan mobil dalam berbagai kondisi. Video direkam dengan menggunakan DJI Mavic Pro dengan resolusi video 1920 x 1080p Pada tahap pre-processing, resolusi citra diperkecil menjadi 540 x 960p untuk mempersingkat waktu pemrosesan citra. Selain itu, tahap ini juga mengkonversi citra yang diekstraksi menjadi citra abu-abu. Kemudian, citra tersebut selanjutnya akan diproses sebagai masukan citra untuk untuk metode frame difference. Proses frame difference membutuhkan citra yang memiiliki kepadatan piksel tinggi yang direpresentasikan dengan $I_{B}(p, q, t)$, sebagai dekomposisi dari citra masukan, dimana $(p, q)$ menunjukkan posisi area dengan kerapatan piksel yang lebih tinggi dari citra asli (Saif, dkkk, 2014). Tujuan dari proses ini adalah ini untuk membuat area citra sensitif terhadap perubahan pergerakan objek yang membawa banyak informasi. $I_{B}(p$, $\mathrm{q}, \mathrm{t}$ ) bisa didapatkan dengan menggunakan Persamaan (1):

$$
I_{B}(p, q, t)=\operatorname{mean}(p, q, t)+\frac{\alpha}{\beta^{2}}\left(N_{1}(p, q, t)-N_{-1}(p, q, t)\right)
$$

Dimana $\alpha$ adalah konstanta yang harus memenuhi syarat $\alpha<1$, mean $(\mathrm{p}, \mathrm{q}, t)$ adalah nilai ratarata dari level nilai abu-abu dari semua piksel dalam area $(p, q)$ pada Frame ke-t, $N_{1}(p, q, t)$ adalah jumlah nilai piksel dengan level abu-abu yang lebih besar dari mean $(p, q, t), N_{-1}(p, q, t)$ adalah jumlah nilai piksel dengan level abu-abu yang lebih kecil dari mean $(p, q, t)$. Dari Persamaan (1), dekomposisi citra $\mathrm{I}_{\mathrm{B}}(\mathrm{p}, \mathrm{q}, \mathrm{t})$ digunakan untuk mendapatkan citra keluaran dari metode frame difference $\mathrm{FD}_{\mathrm{r}}(\mathrm{p}, \mathrm{q}, \mathrm{t})$ dengan menggunakan Persamaan (2). 


$$
F D_{r}(p, q, t)=\left(\frac{\left|I_{B}(p, q, t)-I_{B}(p, q, t-1)\right|}{\frac{F D_{\max }(t)}{256}}\right)
$$

Dimana $F D_{\max }$ adalah nilai piksel maksimum dari fungsi $F D(p, q, t)=I_{B}(p, q, t)-I_{B}(p, q, t-1)$. Hasil citra keluaran dari komputasi dari Persamaan (2) dapat dilihat pada Gambar 2

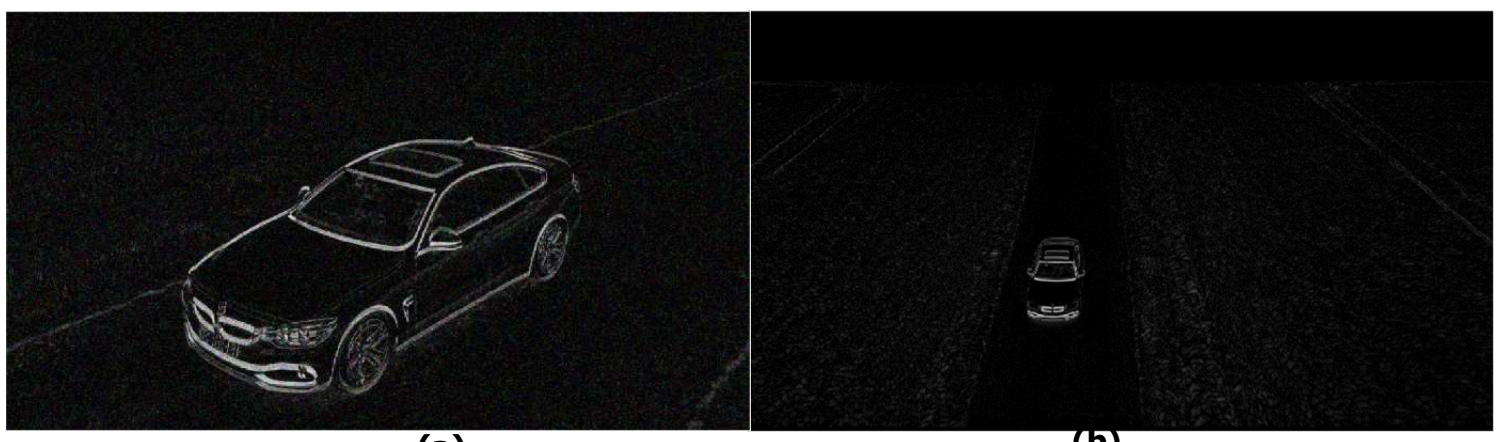

(a)

(b)

\section{Gambar 2. Hasil Citra Keluaran Metode Frame Difference (a) Objek Dekat, (b) Objek Jauh}

Pada kedua citra di atas objek yang bergerak hasil frame difference menunujukkan adanya tepi-tepi yang memiliki tingkat intensitas piksel yang tinggi dibandingkan dengan objek yang lain. Tahap berikutnya, citra keluaran dari Persamaan (2) di-filter dengan menggunakan filter median yang direpresentasikan dengan matriks $3 \times 3, F D_{f}(p, q, t)$, ditunjukkan pada Persamaan (3). Filter median ini memiliki tujuan untuk meminimalisir derau acak seperti derau impulse.

$$
F D_{f}(p, q, t)=\left\{\begin{array}{lr}
1, & F D(p, q, t) \geq T(t) \\
0, & \text { otherwise }
\end{array}\right.
$$

Dimana $\mathrm{T}(\mathrm{t})=$ rata-rata dari semua blok pada Persamaan $F D_{r}(p, q, t)$ pada waktu ke- $t+$ Konstanta Positif*(Puncak terluas dari Persamaan $F D_{f}(p, q, t)$ - Puncak terluas dari Persamaan $\left.F D_{r}(p, q, t)\right)$.

\subsection{Metode Superpixe/Berbasis Edge Detector}

Metode Superpixels dapat menjaga batas objek disetiap wilayah superpixel dengan baik sehingga metode ini dapat digunakan untuk mendeteksi tepi objek. Nantinya dalam setiap wilayah superpixe/ digunakan hubungan antara superpixe/ untuk menentukan tepi-tepi yang harus dipertahankan atau dihilangkan. Setiap wilayah superpixe/ditentukan gradient masingmasing untuk menentukan tepi-tepi objek di wilayah tersebut. Proses deteksi tepi ditiap superpixe/ dimulai dengan menetukan jarak $D_{i j}$ antara wilayah superpixe/ antara satu dan lainnya, superpixel $i$ dan superiksel $j$. $D_{i j}$ di antara dua wilayah superpixe/ yang berdekatan didefinisikan pada Persamaan (4).

$$
\begin{gathered}
D_{i, j}=\left|L_{i}-L_{j}\right|+\left|A_{i}-A_{j}\right|+\left|B_{i}-B_{j}\right| \\
L_{i}=\sum_{c \in S_{i}} \frac{l_{c}}{\left|S_{i}\right|}, A_{i}=\sum_{c \in S_{i}} \frac{a_{c}}{\left|S_{i}\right|}, B_{i}=\sum_{c \in{ }_{i}} \frac{b_{c}}{\left|S_{i}\right|}
\end{gathered}
$$


Dimana $I_{c} a_{c}, b_{c}$ adalah nilai dari piksel yang telah ditentukan oleh CIELAB color space. Kemudian kita menghitung adjacent matriks $A$ dari superpixel (A adalah matriks segitiga atas). Baris ke-i dari A terdiri dari jarak antara superpixe/ ke-i dan tetangganya. Dan untuk A, nilai rata-rata $\bar{A}$ adalah rata-rata dari unsur-unsurnya yang tidak nol. Deteksi tepi akan ditentukan dengan syarat jika $A_{i, j}<\bar{A}$, tepi antara $S_{i}$ dan $S_{j}$ harus dihilangkan, sebaliknya jika tidak maka tepi yang telah dideteksi harus dipertahankan. Adapun prosedur lengkap pemrograman dari metode ini dirangkum sebagai berikut:

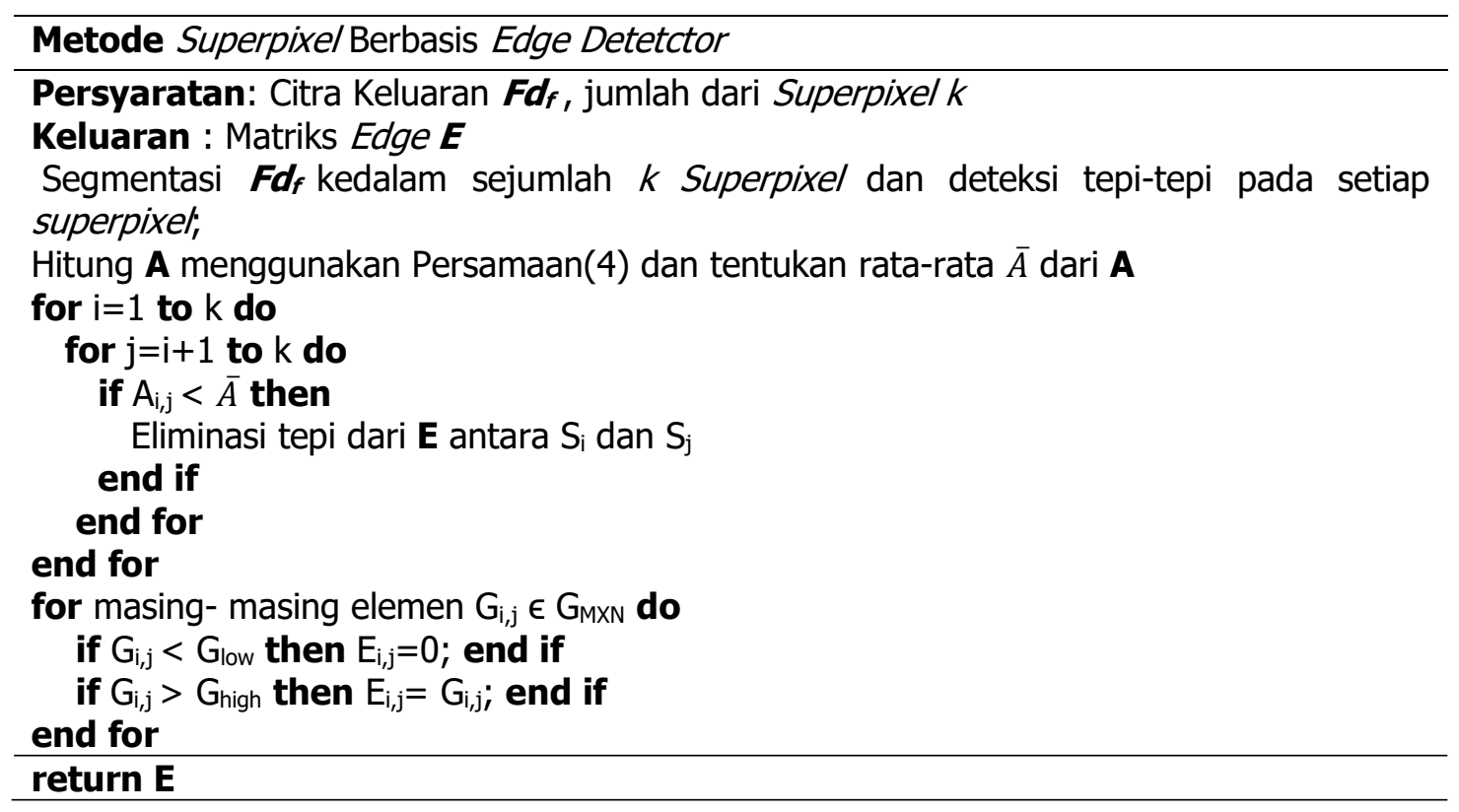

Hasil citra keluaran dari proses pengelompokan dengan metode superpixe/berbasis SLIC. LSC dan SNIC dapat dilihat pada Gambar 3. Pada citra keluaran metode superpixe/ terlihat citra akan dibagi sebanyak $k$ superpixe/ dan proses deteksi tepi akan berlansung di setiap wilayah superpixe/ tersebut. Saat derau muncul, nilai piksel cenderung singular dalam sebuah citra. Sementara cluster centroid biasanya mengambil nilai rata-rata semua piksel dengan label yang superpixe/sesuai, dampak dari derau akan diakumulasikan dalam centroid cluster. Oleh karena itu, derau mempengaruhi centroid cluster dan centroid cluster memainkan peran penting dalam proses clustering dan juga menekan terjadinya derau.

\subsection{Metode Gradien berbasis Deteksi Tepi}

Tepi pada citra digital didefenisikan sebagai perubahan level intensitas piksel abu-abu yang terjadi dengan cepat dalam jarak antar piksel yang singkat. Sedangkan deteksi tepi pada suatu citra adalah suatu proses yang menghasilkan tepi-tepi dari obyek pada citra digital. Tujuannya adalah untuk memberikan label pada bagian yang menjadi detail citra dan memperbaiki detail dari citra yang kabur yang terjadi karena adanya efek dari proses akuisisi citra. Pada Gambar 4. di bawah ini dapat dilihat proses yang dilakukan untuk memperoleh tepi pada citra dengan metode gradien. 


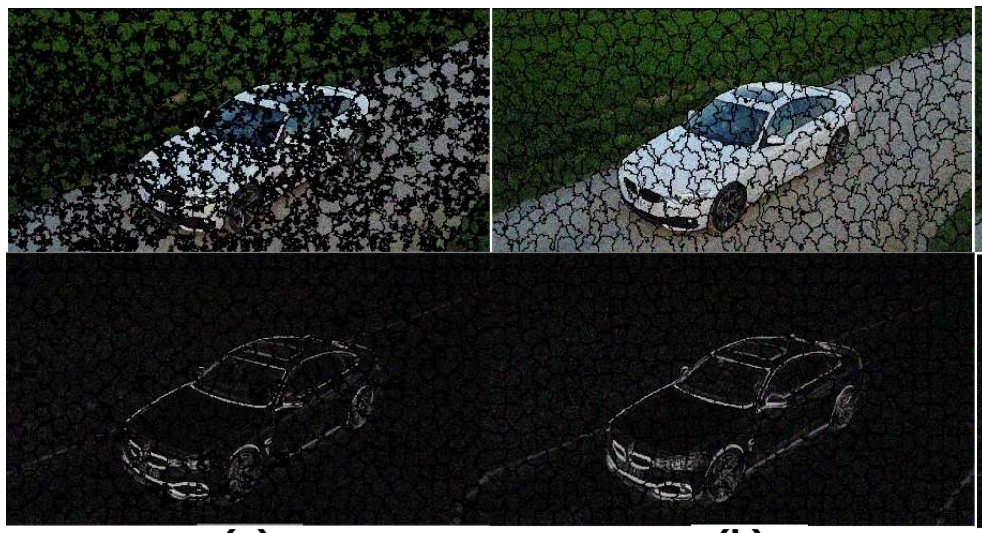

(a) (b)

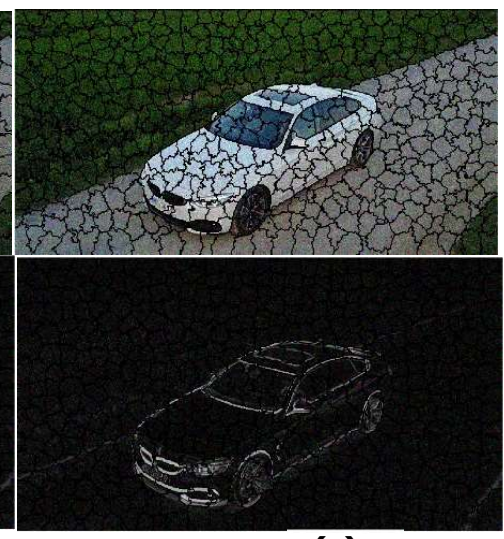

(c)

Gambar 3. Hasil Citra Keluaran Metode Superpixel(a) LSC (b) SLIC (c) SNIC

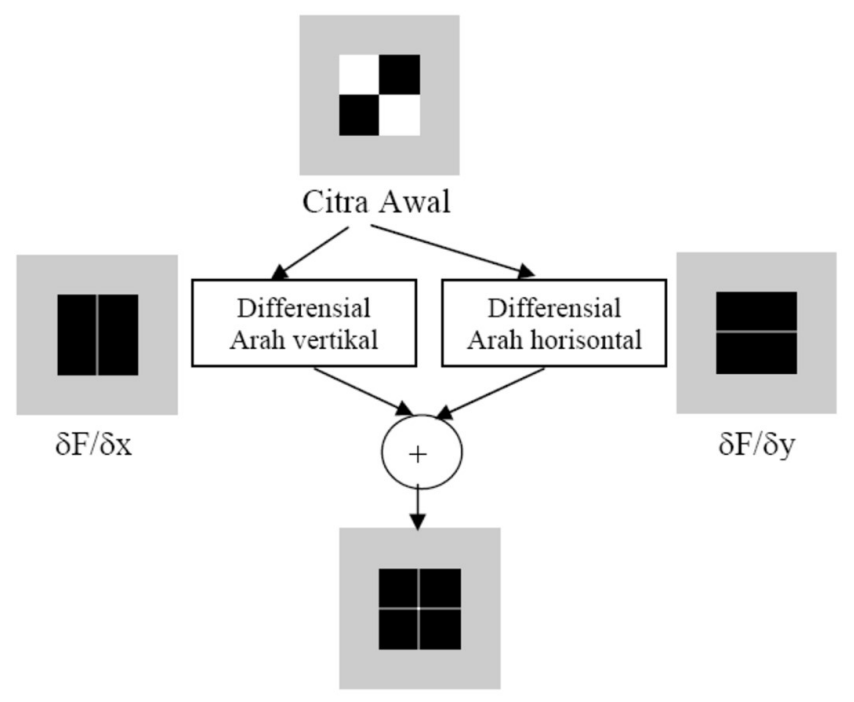

Gambar 4. Proses Deteksi Tepi dengan menggunakan Gradien

Proses deteksi tepi (edge detection) dengan metode gradien sendiri masing dapat dikelompokkan berdasarkan operator atau metode yang digunakan dalam proses pendeteksian tepi suatu citra untuk memperoleh citra hasil. Adapun beberapa operator yang akan digunakan dalam penelitian ini sebagai berikut:

\subsubsection{Operator Robert}

Operator Robert adalah salah satu dari teknik diferensial yang diterapkan pada arah horizontal dan arah vertikal, serta melakukan konversi biner setelah dilakukan Teknik differensial. Teknik konversi biner yang dilakuakan adalah konversi biner dengan menyamaratakan distribusi warna hitam dan putih. Operator Robert ini identikal dengan teknik DPCM (Differential Pulse Code Modulation). Operator Robert menggunakan operator gradien berukuran $2 \times 2$ pada setiap arah diferensialnya yang ditunjukkan pada Gambar 5. 


\begin{tabular}{|c|c|}
\hline 1 & 0 \\
\hline 0 & -1 \\
\hline
\end{tabular}

(a)

\begin{tabular}{|c|c|}
\hline 0 & 1 \\
\hline-1 & 0 \\
\hline
\end{tabular}

(b)

Gambar 5. Gradien pada Operator Robert (a) $\mathbf{G}_{x}(\mathbf{b}) \mathbf{G}_{\mathbf{y}}$

Gradien magnitude dari operator Robert didapatkan menggunakan Persamaan (5) :

$$
G|F(i, j)|=|f(i, j)-f(i+1, j+1)|+|f(i+1, j)-f(i, j+1)|
$$

Karena operator Robert hanya menggunakan konvolusi mask berukuran 2 × 2, maka operator Robert sangat sensitif terhadap derau.

\subsubsection{Operator Prewitt}

Operator Prewitt merupakan peningkatan dari operator Robert dengan memanfaatkan High Pass Filter yang disisipkan satu angka nol sebagai penyangga. Operator ini mengambil prinsip kerja dari fungsi Laplacian yang digunakan sebagai fungsi untuk membangkitkan filter HPF. Operator Prewitt menggunakan kernel ukuran 3 x 3 seperti yang ditunjukkan pada Gambar 6 .

\begin{tabular}{|c|c|c|}
\hline-1 & -1 & -1 \\
\hline 0 & 0 & 0 \\
\hline 1 & 1 & 1 \\
\hline
\end{tabular}

(a)

\begin{tabular}{|c|c|c|}
\hline-1 & 0 & 1 \\
\hline-1 & 0 & 1 \\
\hline-1 & 0 & 1 \\
\hline
\end{tabular}

(b)

Gambar 6. Gradien pada Operator Prewitt (a) $G_{x}(b) G_{y}$

\subsubsection{Operator Sobel}

Operator Sobel merupakan peningkatan dari operator Robert dengan menggunakan filter High Pass yang diberi satu angka nol penyangga. Kelebihan dari metode sobel ini adalah kemampuan untuk mengurangi derau sebelum melakukan proses deteksi tepi. Operator Sobel menggunakan kernel dengan ukuran 3 x 3 seperti yang ditunjukkan pada Gambar 7.

\begin{tabular}{|c|c|c|}
\hline-1 & -2 & -1 \\
\hline 0 & 0 & 0 \\
\hline 1 & 2 & 1 \\
\hline
\end{tabular}

(a)

\begin{tabular}{|c|c|c|}
\hline-1 & 0 & 1 \\
\hline-2 & 0 & 2 \\
\hline-1 & 0 & 1 \\
\hline
\end{tabular}

(b)

Gambar 7. Gradien pada Operator Sobel (a) $\mathbf{G}_{\mathbf{x}}(\mathrm{b}) \mathbf{G}_{\mathbf{y}}$

Operator Sobel melakukan pendeteksian tepi dengan memperhitungkan tepi vertikal dan horisontal. Magnitud Gradien dari operator Sobel didapatkan dengan menggunakan Persamaan (6). 


$$
G|f(x, y)|=\sqrt{G_{x}^{2}+G_{y}^{2}}
$$

\section{HASIL DAN PEMBAHASAN}

Dalam penelitian ini, untuk menganalisis kinerja dari setiap metode deteksi tepi, ada empat parameter yang berbeda yang dapat diadopsi untuk menunjukkan kesamaan dan perbedaan Citra sebagai berikut: Mean Square Error (MSE), Root Mean Square Error (RMSE) dan Peak Signal to Noise Ratio (PSNR). MSE adalah parameter penting untuk mengevaluasi kinerja prediktor dan estimator. Dalam penelitian ini, MSE menghitung perbedaan antara masingmasing operator. Untuk RMSE, parameter ini didefinisikan sebagai pengukuran untuk besaran dalam berbagai magnitude. PSNR diartikan sebagai rasio antara daya optimal sinyal dan daya derau. Semakin besar nilai PSNR, semakin baik kemampuan metode deteksi tepi untuk merekonstruksi citra dan obyek. Dalam penelitian ini. Dalam makalah ini, ada enam metode deteksi tepi yang dievaluasi seperti Superpixel, Sobel, Prewitt, Roberts, Canny, dan LOG. Pada Gambar 8. Menunjukkan hasil perbandingan beberapa metode yang telah disebutkan sebelumnya.

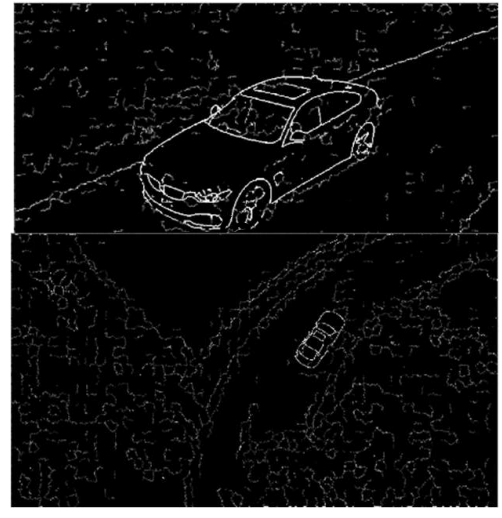

(a)

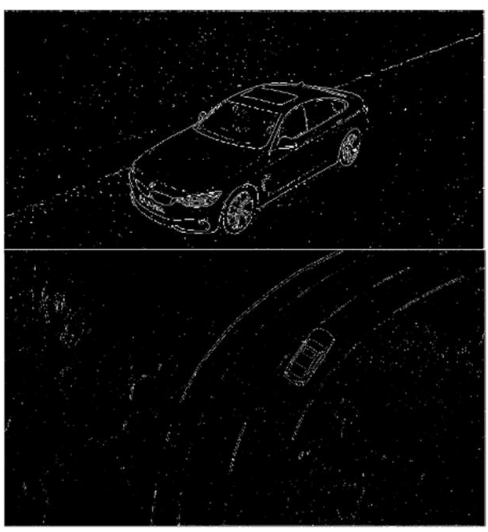

(d)

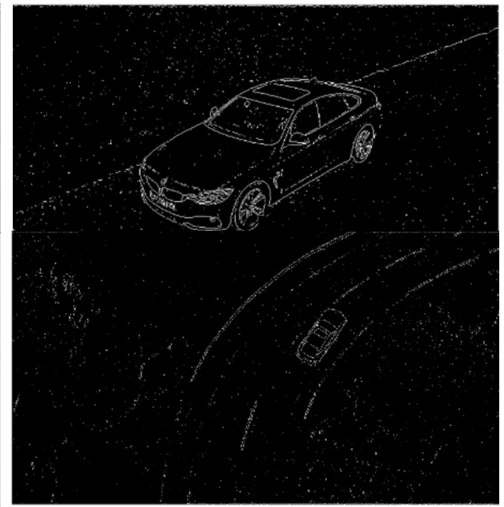

(b)

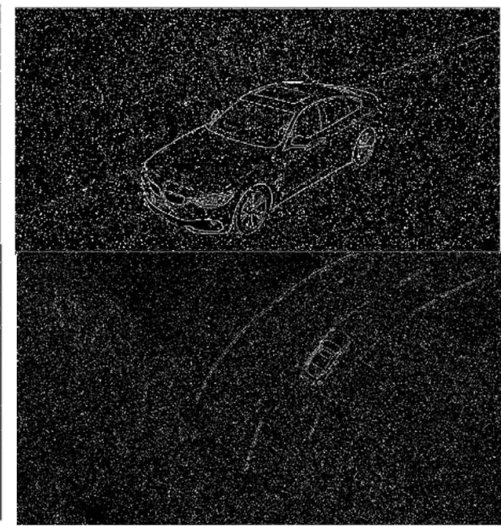

(e)

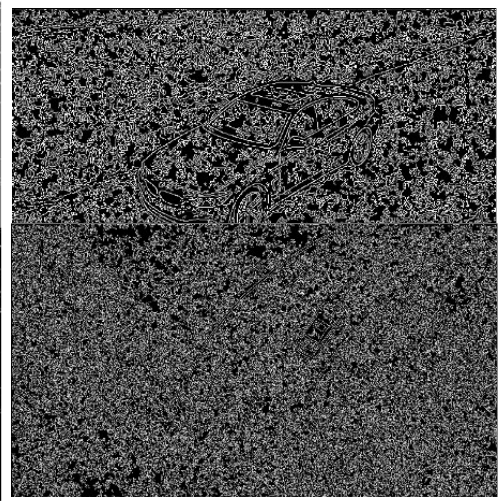

(c)

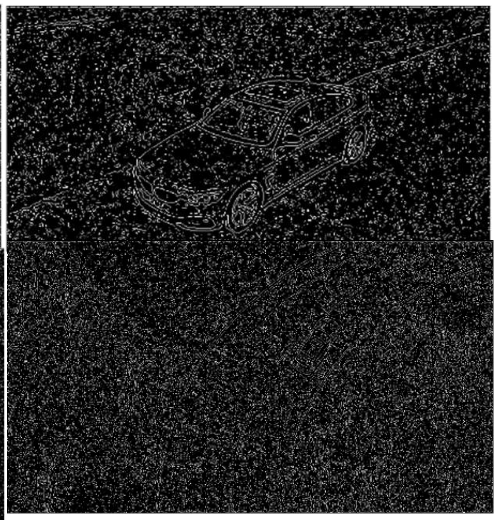

(f)

\section{Gambar 8. Hasil Citra Keluaran Deteksi Tepi (a) Superpixel, (b) Sobel, (c) Canny, (d)} Prewitt, (e) Roberts, (f) LOG 
Dari citra hasil keluaran diatas, bisa dilihat bahwa metode yang mempunyai hasil terburuk dalam meminimalisir derau adalah metode Canny. Metode ini memang memiliki kelemahan dalam sensitifitas terhadap derau sehingga hampir tidak bisa dibedakan antara objek yang dideteksi dan lingkungannya pada kedua citra tersebut. Pada metode Roberts dan $L O G$, proses deteksinya masih banyak terdapat derau tetapi objek yang ingin dideteksi sudah terlihat tepitepinya. Pada citra yang dihasilkan oleh metode Sobe/ dan Prewitt, obyek sudah terlihat dengan jelas khusunya pada citra yang pertama. Hal ini terlihat dari tepi-tepi yang sudah terlihat dengan jelas serta derau sudah terminimalisir dengan dengan baik jika dibandingkan dengan metode Roberts. Pada citra kedua untuk metode Sobel dan Prewitt, level intensitas piksel dari tepi objek yang dideteksi masih terkesan buram dan sulit dibedakan dengan tepitepi yang dibentuk oleh objek sekitar atau lingkungannya. Pada citra yang dihasilkan oleh metode superpixe/ terlihat intenitas piksel pada tepi objek yang dideteksi sangat tinggi dibandingkan dengan sekitarnya sehingga objek sangat bisa deibedakan dengan jelas terhadap lingkungannya. Begitupun pada citra kedua, objek bergeraknya terdeteksi dengan tepi yang mempunya level intensitas yang tinggi dibanding lingkungannya. Adapun bentukbentuk yang tidak beraturan yang terdapat dikedua citra pada metode superpixe/ diakibatkan pada proses pembagian citra menjadi beberapa wilayah superpixe/ sehingga setiap batas wilayah superpixel ikut dipertahankan. Pada citra keluaran metode superpixel berhasil meminimalisir derau dengan sangat baik terlihat tidak adanya titik-titik putih pada kedua citra jika dibandingkan dengan kelima metode yang diuji.

Tabel 1. Perbandingan Kinerja Metode Deteksi Tepi

\begin{tabular}{|c|c|c|c|}
\hline \multirow{2}{*}{ Metode Deteksi Tepi } & \multicolumn{3}{|c|}{ Result } \\
\cline { 2 - 4 } & MSE & RMSE & PSNR \\
\hline Superpixel & $2.1449 \mathrm{e}-04$ & 0.0146 & 84.8507 \\
\hline Sobel & $2.1191 \mathrm{e}-04$ & 0.0146 & 84.9033 \\
\hline Canny & $3.8611 \mathrm{e}-04$ & 0.0196 & 82.2976 \\
\hline Prewitt & $2.1022 \mathrm{e}-04$ & 0.0145 & 84.9381 \\
\hline Roberts & $2.5516 \mathrm{e}-04$ & 0.0160 & 84.0967 \\
\hline LOG & $2.4862 \mathrm{e}-04$ & 0.0158 & 84.2094 \\
\hline
\end{tabular}

Berdasarkan Tabel 1, metode yang memiliki kinerja yang terbaik dalam merekontruksi kembali citra hasil deteksi tepi adalah Prewitt yang memiliki nilai MSE 2.1022e-04. Hal ini disebabkan karena metode Prewitt memiliki kelebihan dalam hal kernel-kernel yang digunakan pada metode ini dapat merespon secara maksimal terhadap tepi-tepi yang terdapat pada arah secara vertikal dan horizontal. Kernelnya juga dapat diaplikasikan secara terpisah pada citra masukan, untuk menghasilkan pengukuran terpisah dari orientasi komponen gradien masingmasing. Kemudian metode yang identikal dengan metode Prewitt adalah metode Sobel dengan nilai MSE 2.1191 e-04. Namun, metode Prewitt sedikit lebih tahan terhadap derau dibanding metode Sobel. Hal ini dapat dilihat lagi pada Gambar 8 (b) dan (d) yang merepresenatasikan kedua metode tersebut. Metode yang memiliki kinerja terburuk untuk pengujian pada objek bergerak adalah metode Canny yang memiliki nilai MSE 3.8611e-04. Hal ini disebabkan metode Canny menggunakan kernel dengan ukuran yang besar untuk mendeteksi tepi yang lebih besar dan lebih halus. Namun, hal itu menyebabkan blurring yang lebih tinggi dan setiap tepi yang terdapat pada objek atau lingkungan bahkan derau citra yang akan dideteksi dipertahankan. Selain itu operator ini membutuhkan banyak waktu karena proses komputasi yang lebih kompleks.

Pada metode Superpixe/ terlihat perbedaan MSE yang didapatkan memiliki perbedaan yang tidak telalu signifikan dengan metode Sobel dan Prewitt. Namun, keuntungan dari metode ini 
Analisis Perbandingan Kinerja Metode Superpixe/ dan Gradien berbasis Edge Detector pada Pendeteksian Objek Bergerak

adalah mampu meminimalisir derau yang terdapat pada citra yang dideteksi dan meningkatkan intensitas piksel tepi dari objek bergerak sehingga objek terdeteksi dengan jelas. Khususnya pada saat objek bergerak yang terletak jauh dari kamera seperti yang terlihat pada Gambar 8 (a) bawah. Metode superpixe/melakukan minimalisir derau di setiap wilayah superpixe/yang bersamaan dengan proses komputasi deteksi tepi dari objek yang ingin dideteksi.

\section{KESIMPULAN}

Berdasarkan dari hasil simulasi dapat disimpulkan bahwa metode superpixel memiliki kemampuan dalam meminimalisir derau lebih baik dibandingkan dengan kelima metode lainnya. Hal ini disebabkan karena dampak dari derau diakumulasikan dalam centroid cluster yang berada di tiap wilayah superpixel. Centroid cluster memainkan peran penting dalam proses clustering dan juga menekan terjadinya derau. Sehingga metode ini sangat cocok untuk mendeteksi objek bergerak untuk skenario objek bergerak yang objeknya dekat maupun jauh dari perekaman. Kemudian, hasil perhitungan dari MSE, RMSE dan PSNR menunjukkan perbedaan yang tidak begitu signifikan dengan metode lainnya seperti Prewitt yang memiliki perbedaan sekitar $0.06 \%$ dan $0.1 \%$ dengan metode Sobel. Namun, pada penelitian ini masih ditemukan kelemahan metode superpixe/yaitu batas-batas antar wilayah superpixe/masih ikut terdeteksi pada proses deteksi tepinya sehingga untuk penelitian selanjutnya akan dijadikan fokus untuk meminimalisir batas-batas ini.

\section{DAFTAR RUJUKAN}

Chandwadkar, Dhole, Gadewar, Raut, \& Tiwaskar. (2013). Comparison of edge detection techniques. Proceedings of Sixth IRAJ International Conference No. 5036.7123.

Heath, Mike, Sudeep, Sanocki, \& Kevin. (1998). Comparison of edge detectors: a methodology and initial study. Computer vision and image understanding. (pp. 38-54).

Mursalim. (2018). Pendeteksian dan Pelacakan Objek Bergerak pada UAV berbasis Metode SUED. Jurnal Nasional Teknik Elektro dan Teknologi Informasi, 71 , , 105-111.

Radhakrishna and Sabine . (2017). Superpixels and polygons using simple non-iterative clustering. in Proceedings of the IEEE Conference on Computer Vision and Pattern Recognition (pp. 4651-4660). IEEE.

Radhakrishna, Appu, Kevin, Aurelien, Pascal, \& Sabine . (2012). SLIC superpixels compared to state-of-the-art superpixel methods. IEEE transactions on pattern analysis and machine intelligence, (pp. 2274-2282).

Saif, Anton , \& Zainal. (2014). Moving object detection using dynamic motion modelling from UAV aerial images. The Scientific World Journal.

Voskuil, R. P. (1996). Bandoeng: Beeld van Een Stad (Indonesian ed.). (S. M. Supardan, S. Sumardi, N. Darsono, \& I. I. Yousda, Penerj.) Bandung: Dept. Planologi and Jagaddhita. 
Wu, C., Zhang, L., Zhang, H. \& Yan, H. (2018). Superpixels using fuzzy simple linear iterative clustering and fast precise number control. arXiv.org (pp. 1812.10932).

Xiaofeng and Jitendra. (2003). Learning a classification model for segmentation. in Proceedings of the IEEE International Conference on Computer Vision (pp. 10).

Zhang, Wu, \& Zheng. (2019). A novel centroid update approach for clustering-based superpixel method and superpixel-based edge detection. arXiv.org. Cornell University.

Zhengqin and Jiansheng. (2015). Superpixel segmentation using linear spectral clustering. Proceedings of the IEEE Conference on Computer Vision and Pattern (pp. 1356-1363). 